\title{
Integrated Study of Measures \& Techniques in Green Building Construction
}

\author{
Namesh Killemsetty ${ }^{1}$, Shridhar A. Behare ${ }^{2}$ \\ ${ }^{1}$ (Department of Civil Engineering, O.P. Jindal Institute of Technology, India) \\ ${ }^{2}$ (Department of Civil Engineering, O.P. Jindal Institute of Technology, India)
}

\begin{abstract}
Conventional buildings produce high amount of greenhouse gas, large quantity of construction and demolition debris (which decrease landfill capacity), disturbs the natural resources and also it consumes a big part of energy and water. Implementation of various simple and sustainable techniques practiced individually can help in many ways to create a structure that is environment friendly, consumes minimal natural resources and at the same time be economical in nature. This paper makes an effort to study the Green Building construction method and new technologies which enables to create a sustainable structure. It also includes design concepts of Green Building, methodology and materials requirement and ideas and suggestions to create a checklist for a builder for him to refer the various suggestions in every phase of construction of a general structure
\end{abstract}

Keywords: Green Building, Energy Consumption, Green materials, Green Roof, Green Wall, , Pottery Wall

\section{Introduction and background study}

The contemporary green building movement arose out of the need and desire to improve the health and economic vitality of people that would lead to creation of energy efficient and environmentally friendly building practices. With an increasing limitation in India's conventional energy reserves, a lot of stress has been laid under the Integrated Energy Policy on energy efficiency and conservation, with particular emphasis on efficiency of electricity generation, transmission, distribution and end-use. Over the next 25 years energy efficiency and conservation would be very critical to ensure energy security and economic growth. The market for Leadership in Energy and Environmental Design (LEED)-rated green buildings in India is projected to increase to $€ 3.7$ billion by 2012 . The total market for green building materials and equipment in India is estimated to be more than 10 times the size of the LEED-rated green building market in India. India's green building footprint has grown from 20,000 sq ft in 2005, to projects covering 914.33 million sq ft by end-2011.

A variety of green building projects are planned or have been completed, including exhibition centers, residential complexes, hospitals, IT parks, educational institutions, laboratories, airports, corporate offices and government buildings. The projected market potential for green building material and technologies was estimated to be $€ 73.4$ billion in the year 2012. According to statistics compiled by IGBC: India has 1297 registered buildings, 201 certified buildings and 914.33 million sq $\mathrm{ft}$ of green building footprint. This puts India firmly on the 2nd spot only behind the U.S in total green building footprint. (Dr. Poonam Kumar, 2013)

By now, every country in the world has been aware of the concepts of Green Building and all of them are now trying to achieve remarkable milestones in this regards. In this direction, one of the attempts is to establish a central agency for Green Building integrating major global green building agencies such as LEED, IGBC (India), CASBEE (Japan), Protocollo Itaca (Italy), BREEAM (Europe) and many other such organizations with the sole purpose to establish essential Green Building Practices, material applications as well as its associated benefits and make some global benchmark guidelines which can be practiced and implemented anywhere

To make a building sustainable, the building must obey the 3 R's of sustainable development i.e. Reduce, Reuse \& Recycle and 3 principles of sustainability i.e. Economy of material. Life cycle design and Human Design. All other things fall under these principles.

\section{The 3 Principles of Sustainable Development:}

1. Reduce

To make a building sustainable, one must be able to reduce the energy consumption of the building either through active or passive design approach. Applying active approach involves making use of specific hardware to reduce the rate at which the building consumes energy and passive approach involves tending to build with some building materials which are effective in energy conservation. Reducing the amount of hard surface landscape elements by landscaping with more grasses, shrubs, and trees also reduces the effect of solar radiation on a building which can cause unnecessary heating of the building. 


\section{Reuse}

Reuse refers to making sure that nothing is wasted in the building either in terms of materials or energy. Sustainable buildings make use of renewable sources of energy like solar, wind Etc

\section{Recycle}

The use of recyclable materials like bricks, wood, paper, plastic, glass, Etc. makes a building sustainable.

\section{The 3 Principles of Sustainability}

\section{Economy of Material}

The waste found on the site of a sustainable building is very minimal; this is because it employs the principle of economy of materials in its designs. In a well-designed Sustainable building, no material is wasted as they are either recycled or converted for use in other areas.

\section{Life Cycle Design - L.C.D}

The L.C.D principle of a sustainable building enables it to be able to lower cost, make the building efficient, and usable from cradle to grave and reusable again. To make a building sustainable, it must be able to fulfil life cycle principle in such a way that materials can be used, recycled and be reused again, energy can also be renewed, a continuous cycle of building life can be maintained Etc.

\section{Human Design}

Any sustainable building must aim at creating a livable and workable environment for humans and the nature around. A well designed sustainable building must create an ecosystem where all organisms live in harmony.

\section{Green building techniques}

Keeping in mind the principles of Sustainable development and Sustainability for creation of a green building, an effort has been made to create a step by step procedure for creation of a green building starting from scratch involving sustainable solutions and suggestions at every phase of construction for a structure.

\section{Site Selection}

Following points should be considered with respect to site selection:

\subsection{Design to include existing site features}

The natural functions of a plot of land can be seriously disrupted by the placement of building on it. The design of a green building is to be done in ways in which the natural site features can be protected or restored. The layout and setting up of site activities and building requirements should be done after carrying detailed site analysis so as to ensure sustainable site development in tune with its topographical, climatic, and ecological character. (Mishra, 2011)

\subsection{Protection of native soil}

Mostly, a building site is cleared of vegetation and top soil is removed during construction. The top soil is essential for landscape. Vegetation reduces the solar radiation which is directly linked with ambience temperature around houses. Therefore retaining native vegetation is must. The key points which should be considered during construction phase are delineate and limit the construction footprint; restrict heavy equipment that compacts soil, including cars. When grading is unavoidable, identify areas to be paved as a place to store native topsoil during construction. Amend soil with compost and re-spread topsoil after construction phase. Preserving native soils can significantly reduce storm runoff, reduce fertilizer requirements, reduce pesticide requirements, improve water quality and conserve irrigation water. 


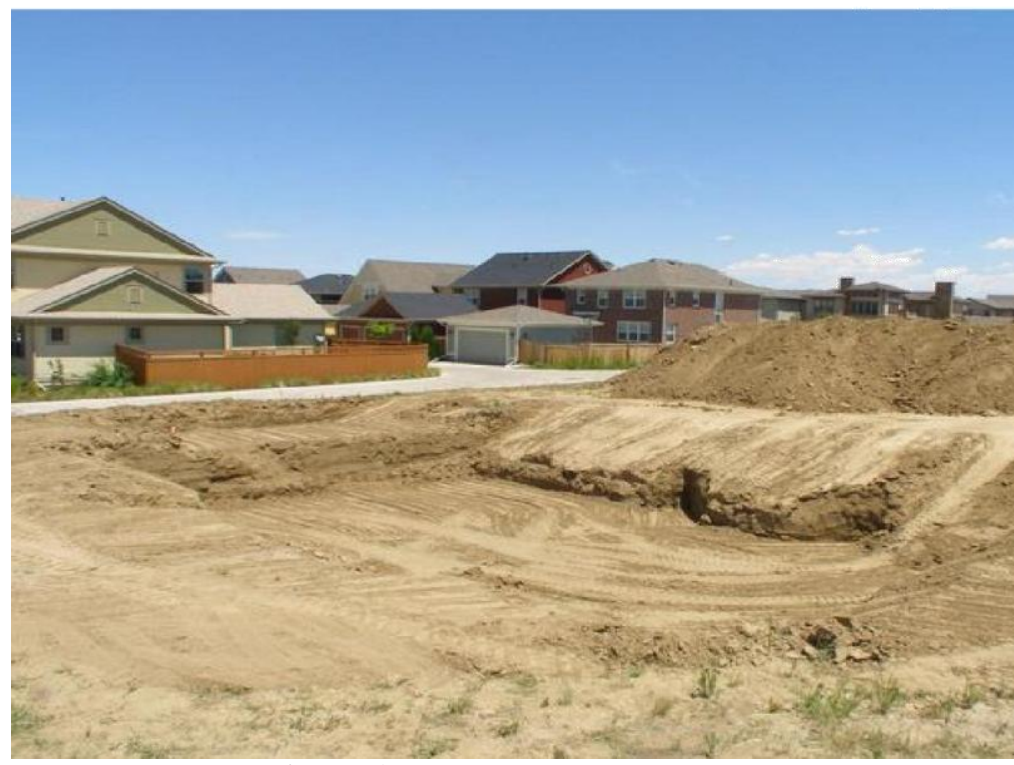

Figure 1: Soil arrangements on site

\subsection{Use of site water catchment}

There is availability of naturally existing pits (i.e. water catchment) at a construction site which can be enhanced in a better way to store and utilize rainwater. As construction of a multi-storeyed building cannot be completed within a year in most of the cases, construction phase often has to encounter with the monsoons. So, to utilize the storm water the naturally available pits can be useful. These pits can be served as storage tanks. Water stored in it can be used for landscape irrigation, construction purpose and also for curing. Water catchment reduces the need to use, drinkable water for watering of lawns and gardens. Implementing this can reduces $15 \%$ to $20 \%$ of water requirement for construction of any multi-storeyed building as per surveyed result of EPA (Environmental Protection Agency).

\subsection{Minimizing the disruption of existing flora}

Trees are the important part of ecosystem. They provide oxygen which is essential for all living things. However due to rapid construction these days, the numbers of trees are decreasing rapidly day by day. People are unaware about on utilizing the presence of trees in the nearby construction field. Through careful planning and construction practices, valuable trees and plants can be preserved in existing developments. During construction phase complete a landscape survey is needed to determine the feasibility of preserving or relocating mature trees and shrubs. Use fence trees and shrubs for protection from equipment. Preserving existing, mature landscape features helps prevent soil erosion, maintains existing sources of natural cooling, divert waste from landfills and maintains the Oxygen level of nearby surroundings.

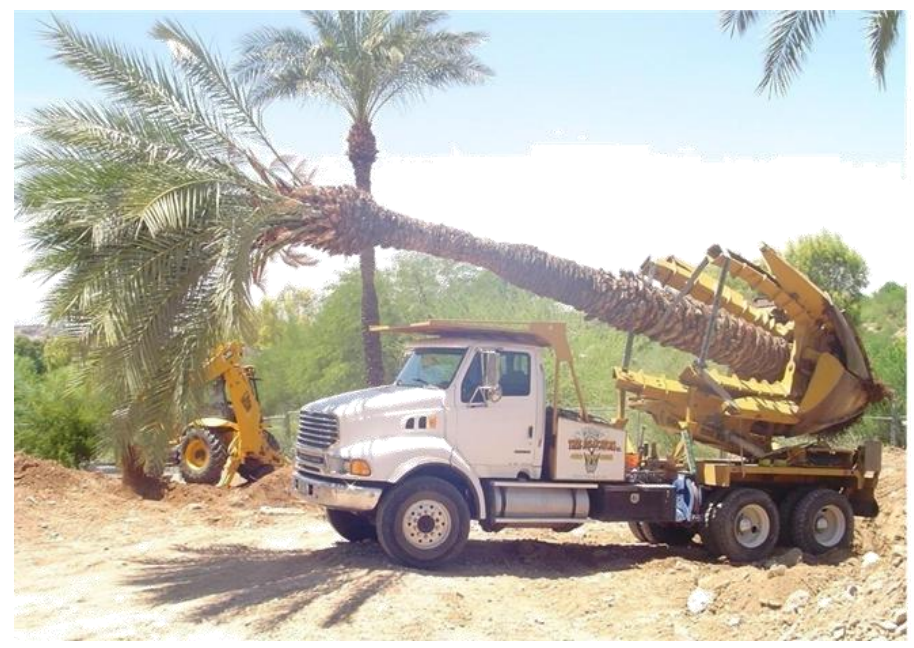

Fig 2: Replantation of Tree 


\subsection{Orientation of Building}

There are several basic parameters for building orientation that are incorporated in any passive solar design. The site where the building will be located must have access to the sun, especially between 9 am and 3 $\mathrm{pm}$, during the heating season, and there should be no more than 20 percent blockage along the sun's path (City of Austin's Green Building Program 2004). A long, thin building with one of the longer sides facing south and most of the windows on the southern wall will allow for maximum solar exposure during the winter months, providing both heat and light. An open floor plan placing the rooms requiring the most light and heat along the south face of the building optimizes passive system operation. Garages, storage rooms, and other such spaces can act as thermal buffers when located on the east and west side of a building (Consumer Energy Centre 2004). Window should be operable to allow for better temperature control. South windows should be shaded by overhangs or awnings. The shade provided should prevent direct sunlight in the summer months but allow maximum sunlight penetration into the building in the winter months, deciduous trees provide optimal shading for the east and west sides of the building. During warmer months, the shading provided by the canopies of leaves and the transpiration of trees will contribute to the cooling needs of the building. However, the trees do not block the sun in the winter (Geller 2003)

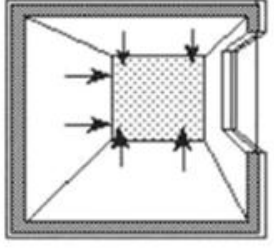

NIGHT
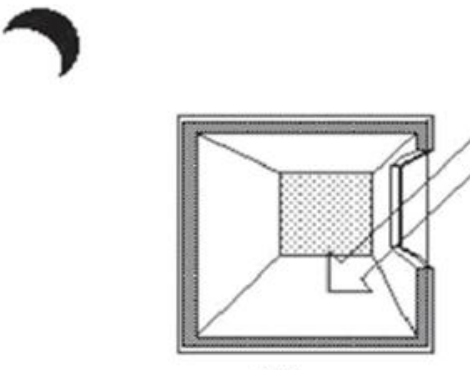

DAY

Figure 3: Orientation of windows in a building

\section{Foundation and Walls}

\subsection{Insulation for heat transfer}

Walls and foundations should be designed such that they can restrict the transfer of heat through them. In cold region, it is necessary to maintain the heat inside the room and in hot region, transfer of heat from outer side should be prevented to reduce the workload of heating appliances for colder region and workload of cooling appliances for hot region. For this purpose the better solution is to provide insulation on the walls with extruded polystyrene insulation of at least 1 inch.

\subsection{Use of Fly ash}

Fly ash is a byproduct of coal burning power-plants and can be a substitute for a portion of Portland cement used in concrete. Typically, $15 \%$ to $50 \%$ of cement can be replaced with fly ash in residential concrete mixes. Fly ash increases the strength and durability of concrete which are used in foundation. Using fly ash also reduces the amount of cement needed, thereby decreasing the overall environmental impacts of cement production.

\section{Structural Frame}

\subsection{Use of lumbers}

Lumbers have property of heat resistance and strength wise they are good enough. In any building as per strength requirements, lumbers can be used in place of steel studs and can also be used as pillars. In ancient practices lumber were used in roofs along with thick layer of soil above it and such practices maintains the temperature inside the house in such manner that it creates opposite environment as compared to outside environment (i.e. They maintain environment of inside of room cool in summer and vice versa). 


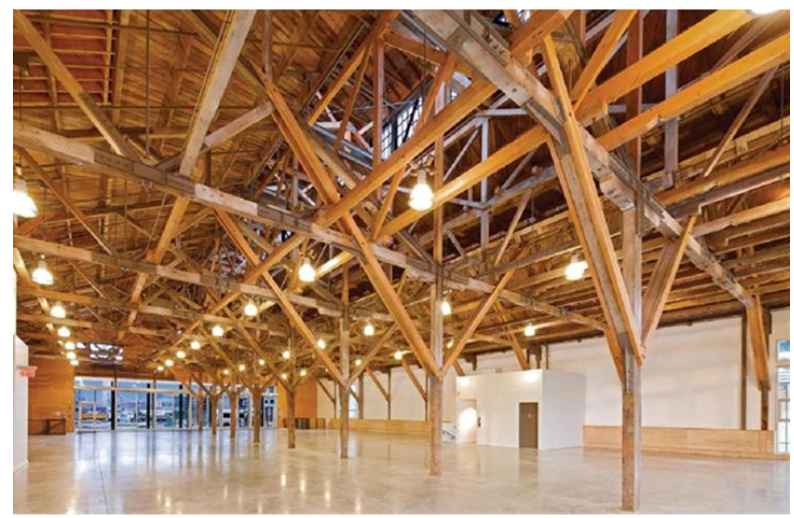

Figure 5: Use of lumbers for structural framework.

\subsection{Used of recycled materials}

Mainly steels are used in structural frame of building like steel pillars, steel studs etc. Use of recycled materials should be preferred over virgin materials. Recycled steel studs can be utilized for further interior framing and this will reduce the load of steel production which ultimately leads to reduction of impact to environment by steel production and saves materials as well as money.

\section{Exterior Finish}

The exterior finish of building can be utilized to reduce effect of solar radiation and some water management tools can also be implemented. Some of the points which can be considered for green building are as follows:-

\subsection{Use of creepers}

Creepers are any plants that grow along the ground, around another plant, or up by a wall by means of extending stems or branches. Creepers can reduce the effect of solar radiation as well as create cold climatic conditions. These are to be planted near the walls.

Figure 5: Use of creepers in wall

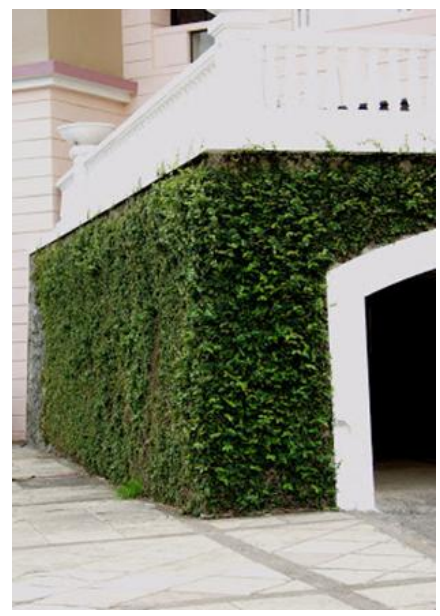

\subsection{Use of Pottery water wall}

Pottery water walls are such walls which consist of pottery pipes inside the walls. These are generally installed in arid reason. These pipes contain water from kitchen utensils and urinals and are circulated around the whole building. When solar radiation strikes the wall, the water inside the pottery pipes absorb the thermal energy and exchange heat as per thermal conditions. Pottery water wall stores solar heat during the day and releases or radiates it throughout the cooler night. 


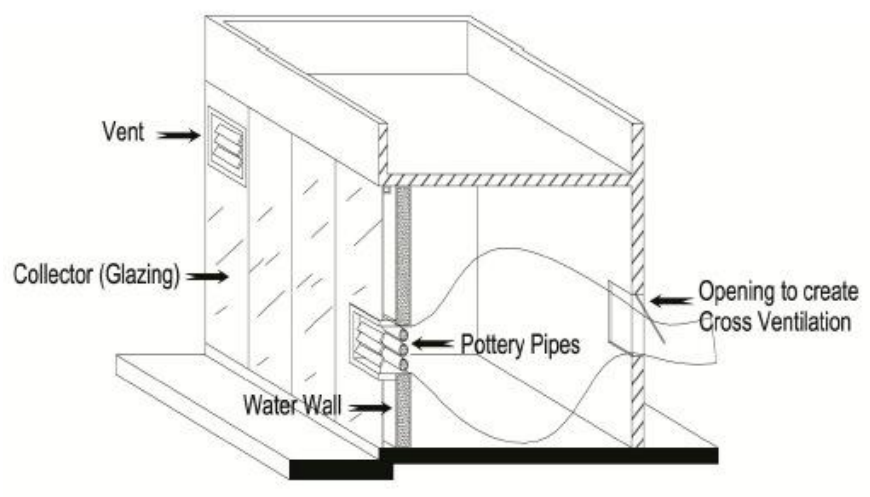

Figure 6: use of Pottery water wall

In hot, sunny, arid climates that have a large range in temperature from day to night and where humidity is desired, the use of a water wall stabilizes the inner passively warmed and cooled temperatures. Both water and adobe has the ability to stabilize temperature swings. During the night, the temperature is typically cold while the water in the water wall is hot from the solar radiation stored during the day. The stored heat passively warms the living quarters with radiant heat during the cooler night. As the water wall releases its heat, it slowly cools. By the morning, the wall is cold, and will slowly warm as the sun shines on it. Because of its mass, it will not immediately warm, and will work to keep the house cool.

The Pottery Water Wall allows for both evaporation and ventilation from the earthen piping increasing humidity within the home. The wall cools the living quarters with ventilation and evaporation, as the air passing by the pipes is much cooler in the early morning and afternoon. The lack of ventilation and humidity in dry desert environments is solved by introducing this simple concept

\subsection{Solar Wall Photo-voltaic/Thermal - Hybrid Heating and Electricity}

Solar Wall PV/T (photovoltaic + solar thermal) is a hybrid system which provides up to 4 times the total energy from the same surface area. The secondary benefit is to reduce the operating temperature of the PV modules and thereby improve electrical performance. The patented system provides both PV generated electricity and warm air for building ventilation or process heating. As well, the Solar Wall component becomes the PV racking system, which further reduces PV system costs.

Solar Duct PV/T is a modular rooftop application of the PV/thermal technology that also acts as a PV racking system. PV modules are mounted on top of the Solar Duct units, and the heat is drawn off the back of the PV modules and then ducted to the nearest rooftop air handler. The 'excess heat' is then channeled into the building's HVAC system where it is used to offset the heating load. The removal of the heat from the back of the PV modules also enhances the electrical operating efficiency of the PV by up to $10 \%$. Since the Solar Wall air heating panels serve as the racking system needed to mount the PV modules that also contribute to the costeffectiveness of the cogeneration system. The modular units are easy to install and are angled at an ideal orientation for maximum solar gain.

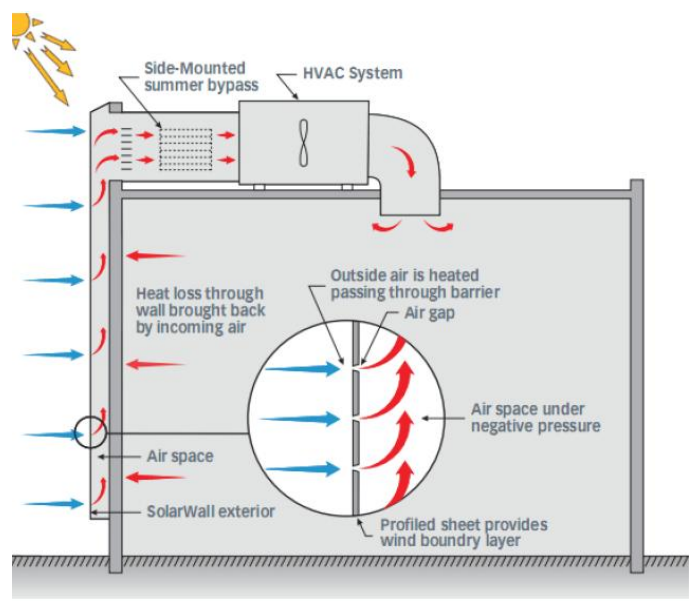

Figure 7: Function of Solar Wall (Lewis, 2008) 


\subsection{Solar Windows}

Solar Window is an organic photovoltaic (OPV) solar array composed of ultra-thin layers forming small cells. Solar Window generates clean electricity on see-through glass windows, by making use of the energy of natural sunlight and artificial sources such as fluorescent and LED lighting typically installed in offices, schools, and commercial buildings. The coating is an organic photovoltaic solar array composed of ultra-thin layers forming small cells, using mostly hydrogen-carbon based substances. When interconnected in a grid-like arrangement, an array of these OPV cells increase the voltage potential and electrical current in a given area. The electricity-generating coating that produces electrical energy from natural and artificial light can be applied to the entire façade of a building or applied on surfaces at low-temperatures and atmospheric pressures. It can also be used in conjunction with existing energy conservation technologies such as low E coatings. When applied to the façade of an office building, Solar Window is capable of generating over 300 percent the energy savings of traditional rooftop panels. New Energy Technologies, Inc.'s Solar Window technology utilizes an organic solar array composed of a series of ultra-small solar cells measuring less than $1 / 4$ the size of a grain of rice each. They are fabricated using environmentally-friendly hydrogen-carbon based materials, and successfully produce electricity.

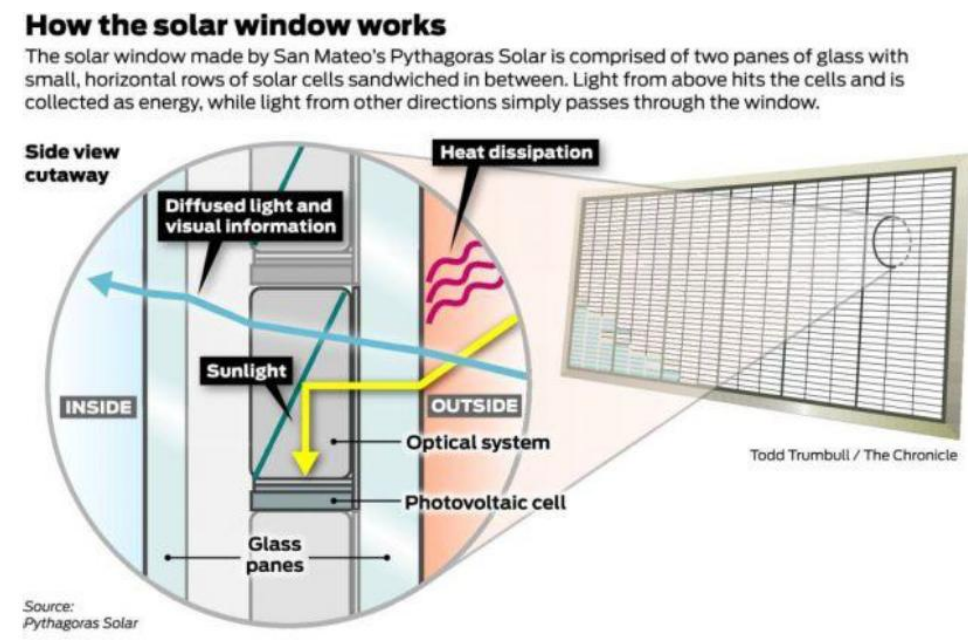

Figure 8: Working of Solar Windows

\section{Use of Green Roofing}

Green Roofing is a new concept used now a days, in which terrace is planted with small plants which can reduce the temperature of a building. The plants at the terrace absorb the solar radiation and thereby reducing the ambience temperature. Green roofing also filters the storm water which can be used for irrigation purpose.

The main motivation for extensive green roofs was the restoration of nature and protection of the roof membranes from the elements and temperature fluctuations. Today, ecological benefits such as reduced energy consumption for heating and cooling, stormwater retention, and heat island mitigation are the main reasons for the growing popularity of green roofs. Other benefits include habitat restoration, filtration of acid rain and air pollutants, noise pollution reduction, and the therapeutic effects found from being in the presence of nature. (Technology, 2014)

Plant diversity is the key for long-term sustainability, reduced maintenance and enhanced green roof benefits. Creating plant diversity requires an advanced level of horticultural knowledge and sufficient experience of practical/ hands on green roof maintenance. Diverse green roofs habits prohibit the use of chemical growth and weed control substances. 


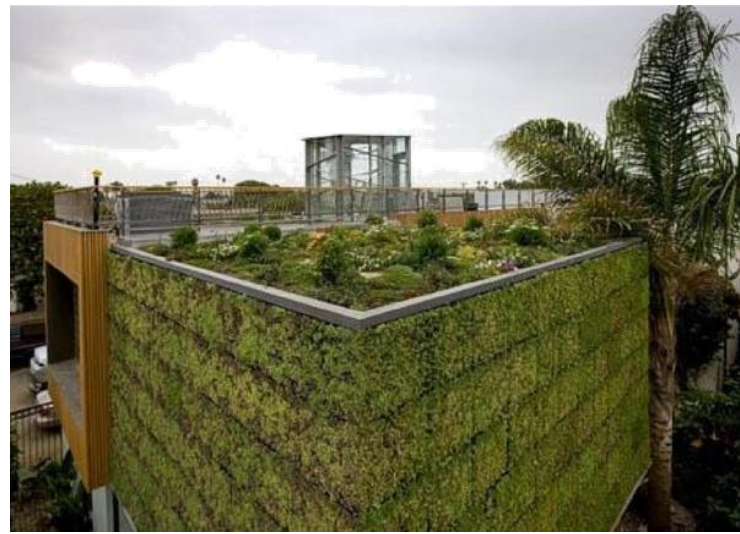

Figure 9: Green walls with green roof

\section{Solar Duct - Modular rooftop solar air heating system}

Solar Duct is based on the highly efficient and award-winning Solar Wall system. The technology has been specifically engineered for roof settings and for applications in which a traditional wall mounted system is not feasible.

Like the original Solar Wall technology, Solar Duct is a solar heating system that heats ventilation air before it enters the air handling units. The patented system uses an all-metal collector panel (transpired solar collector) and is suitable for commercial, industrial, and institutional facilities. Perforations in the panels allow the heat that normally collects on a dark surface to be uniformly drawn through the Solar Duct panel and then ducted into the conventional HVAC system.

The Solar Duct system is optimized to meet site conditions in terms of orientation towards the sun and proximity to rooftop air handling units. The modular arrays are sized according to the energy requirements of the building.

\section{Plumbing}

Various surveys show that lots of water is wasted due to improper plumbing operation. With the help of proper plumbing we can save large amount of water. The operations which can be considered in plumbing are explained below.

\subsection{Sensor Taps}

Large amount of water is wasted due to use of conventional taps. There are some special sensor taps available in the market which automatically stops when no one is using it.

\subsection{Insulating the Pipes}

Most of the building uses fiber water tanks from where water flows through pipes under the action of gravity. The pipes containing water generally gets hot and cooled depending on the climatic condition. To maintain the desired temperature proper insulation of pipes are must.

\subsection{Flush Toilets}

Every time when toilets are flushed that could generate just a little bit of power. That is the idea behind the Benkatine Turbine by Leviathan Energy, which aims to get power from any pipe that water rushes through. So not only one can install this within a municipal system, but according to the company, one could get power from the water rushing down the gutter drains! The basis is similar as hydroelectric power. It is the location and scale of this system that makes it such an innovative product. The turbine is intended to be scalable, meaning that it can work well in both municipal water and sewer systems, as well as in smaller pipes such as residential drainage and guttering systems. It is meant to be used in conjunction with other turbines in order to maximize the efficiency of the system.

\section{Ventilation and Natural Heating \& Cooling}

Natural Ventilation Natural ventilation, also called passive ventilation, uses natural outside air movement and pressure differences to both passively cool and ventilate a building. Natural ventilation is important because it can provide and move fresh air without fans. For warm and hot climates, it can help meet a building's cooling loads without using mechanical air conditioning systems. This can be a large fraction of a building's total energy use. Successful natural ventilation is determined by having high thermal comfort and 
adequate fresh air for the ventilated spaces, while having little or no energy use for active HVAC cooling and ventilation.

\section{Lighting}

Lighting of any building consume large amount of energy. Production of active energy harms environment. They cannot be avoided because now a day they are part of our life. But they can be reducing by adopting certain passive energy. Solar panel can be used to generate passive energy which can be utilized by building. There is a new technology used nowadays known as solar window. Solar window are capable of generating light during night time also. Use of bottle filled with water can be a replacement of conventional bulbs during day time. Water in the bottle disperses the light and they seem like a bulb and produce light. Implement separate electrical supply for appliances like coolers and AC with the collaboration of sensor with a timer which automatically switched off after 3 A.M. Generally, after 3 A.M. the temperature is gentle so one can sleep comfortably during these hours.

\section{Checklist}

Integration of all these measures and suggestions can be used to create a checklist which can enable a builder or an organization to follow all possible implementations during each phase of construction of a structure. The checklist allows a builder to identify the necessary steps to be implemented periodically as each phase of construction progresses and apply the suggestions as the work moves ahead. These kind of checklists have been created by various non profit organizations like LEED and Build it Green in the United States where they certify a house to be a green building only after a builder incorporated all the features in a home. Each feature is assigned points and after accumulating a minimum number of points, the building can be credited.

\begin{tabular}{|c|c|c|}
\hline S.NO. & PHASE & SUGGESTIONS \\
\hline \multirow{8}{*}{1} & \multirow{8}{*}{ SITE PREPARATION } & 1. Protect Topsoil and Minimize Disruption of Existing Plants \& Trees \\
\hline & & a. Protect Topsoil and Reuse after Construction \\
\hline & & b. Limit and Delineate Construction Footprint for Maximum Protection \\
\hline & & 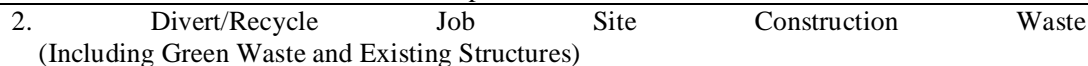 \\
\hline & & 3. Use Recycled Content Aggregate (Minimum 25\%) \\
\hline & & 4. Cool Site: Reduce Heat Island Effect On Site \\
\hline & & 5. Construction Environmental Quality Management Plan, Duct Sealing, \\
\hline & & $\begin{array}{l}\text { a. Duct openings and other related air distribution component openings shall be covered during } \\
\text { construction. }\end{array}$ \\
\hline \multirow{7}{*}{2} & \multirow{7}{*}{ FOUNDATION } & 1. Replace Portland Cement in Concrete with Recycled Fly Ash and/or Slag (Minimum 20\%) \\
\hline & & 2. Use Frost-Protected Shallow Foundation in Cold Areas \\
\hline & & 3. Install a Foundation Drainage System \\
\hline & & 4. Moisture Controlled Crawlspace \\
\hline & & 5. Design and Build Structural Pest Controls \\
\hline & & a. Install Termite Shields \& Separate All Exterior Wood-to-Concrete Connections \\
\hline & & b. All Plants Have Trunk, Base, or Stem Located At Least 36 Inches from Foundation \\
\hline \multirow{8}{*}{3} & \multirow{8}{*}{ LANDSCAPE } & 1. Construct Resource-Efficient Landscapes \\
\hline & & 2. Plant Shade Trees \\
\hline & & 3. Install High-Efficiency Irrigation Systems \\
\hline & & 4. Minimize Turf in Landscape Installed by Builder \\
\hline & & 5. Incorporate Two Inches of Compost in the Top 6 to 12 Inches of Soil \\
\hline & & 6. Rain Water Harvesting System \\
\hline & & 7. Irrigation System Uses Recycled Wastewater \\
\hline & & $\begin{array}{l}\text { 8. Use Environmentally Preferable Materials for } 70 \% \text { of Non-Plant Landscape Elements and } \\
\text { Fencing }\end{array}$ \\
\hline \multirow{4}{*}{4} & \multirow{4}{*}{$\begin{array}{l}\text { STRUCTURAL } \\
\text { FRAMEWORK }\end{array}$} & 1. Apply Optimal Value Engineering \\
\hline & & 2. Construction Material Efficiencies \\
\hline & & 3. Use Engineered Lumber \\
\hline & & 4. Use Solid Wall Systems for floors, walls and roofs \\
\hline \multirow{5}{*}{5} & \multirow{5}{*}{ EXTERIOR } & 1. Use Environmentally Preferable Decking \\
\hline & & 2. Flashing Installation Techniques Specified and Third-Party Verified \\
\hline & & 3. Install a Rain Screen Wall System \\
\hline & & 4. Use Durable and Non-Combustible Siding Materials \\
\hline & & 5. Use Durable and Fire Resistant Roofing Materials or Assembly \\
\hline 6 & INSULATION & 1. Install Insulation with 75\% Recycled Content in walls, ceilings and floors \\
\hline \multirow{4}{*}{7} & \multirow{4}{*}{ PLUMBING } & 1. Distribute Domestic Hot Water Efficiently \\
\hline & & a. Insulate All Hot Water Pipes using engineering parallel plumbing \\
\hline & & 2. Water Efficient Fixtures \\
\hline & & a. High Efficiency Showerheads, Bathroom, Kitchen \& Utility faucets \\
\hline \multirow{2}{*}{8} & \multirow{2}{*}{$\begin{array}{l}\text { HEATING, } \\
\text { VENTILATION \& AIR } \\
\end{array}$} & 1. Properly Design HVAC System and Perform Diagnostic Testing \\
\hline & & 2. Install Sealed Combustion Units like furnaces and water heaters \\
\hline
\end{tabular}


Integrated Study of Measures \& Techniques in Green Building Construction

\begin{tabular}{|l|l|l|}
\multirow{n}{*}{} & CONDITIONING & 3. Install High Performing Zoned Hydronic Radiant Heating \\
\cline { 3 - 3 } & & 4. Install High Efficiency Air Conditioning with Environmentally Preferable Refrigerants \\
\cline { 3 - 3 } & & 5. Design and Install Effective Ductwork \\
\cline { 3 - 3 } & & 6. Install Mechanical Ventilation System for Cooling (Max. 4 Points) \\
\cline { 3 - 3 } & & 7. Automatically Controlled Integrated System with Variable Speed Control \\
\hline \multirow{3}{*}{9} & FINISHES & 1. Design Entryways to Reduce Tracked-In Contaminants \\
\cline { 3 - 3 } & & 2. Use Recycled-Content Paint \\
\cline { 3 - 3 } & & 3. Use Environmentally Preferable Materials for Interior Finish \\
\hline \multirow{2}{*}{10} & FLOORING & 1. Use Environmentally Preferable Flooring ( Minimum 15\% Floor Area) \\
\cline { 3 - 3 } & &
\end{tabular}

\section{Conclusion}

All the proactive steps and suggestions mentioned in the previous pages enable a person or an organization to put forward and create a structure that includes all possible measures to create a sustainable building making it being termed as a green building. This paper enables a user to gather and assimilate all the information required to create a structure a green building and convert an existing structure a green building in most of the senses and apply it in the necessary form. The end result of all these measures is to be able to construct a green building which can reduce energy usage and life cycle cost, create a better environment for occupants, reduce use of water and consumption of natural resources and reduce generation of environmental pollution. Contractors, Builders and consultants are required to acquire the concept of green building in construction field to make awareness among the common people and to increase the contribution more and more people in the field of Green Building.

\section{References}

[1]. U.S. Green Building Council. (n.d.). Retrieved March 5, 2014, from Leadership in Energy \& Environmental Design: http://in.usgbc.org/leed

[2]. BREEAM. (2010). Retrieved March 19, 2014, from Building Research Establishment's Environmental Assessment Method: http://www.breeam.org/

[3]. Development, M. o. (2011). Urban India . Retrieved April 5, 2014, from urbanindia.nic.in/publicinfo/swm/chap4.pdf

[4]. Dr. Poonam Kumar, D. L. (2013). Green Buildings in India: A Path Ahead For Sustainable Development. International Journal of Scientific Research, 1-2.

[5]. GW Planet For Ward. (2009). Retrieved April 10, 2014, from http://www.planetforward.org/idea/spray-on-a-power-plant-for-everybuilding-how-to-generate-electricity-on-existing-windows

[6]. IGBC. (2008). Retrieved March 12, 2014, from Indian Green Building Council: http://igbc.in/site/igbc/index.jsp

[7]. Kaur, A. (2011). Sustainability, Heritage and India's Urban Development: Issues \& Challenges in the Field of Architecture.

[8]. Kumbhkar, D. A. (2012). India: The Way Towards Energy and resource efficient buildings . Bureau of Energy Efficiency .

[9]. Lewis, D. (2006). BC Sustainable Energy Association . Retrieved March 6, 2014, from http://www.bcsea.org/learn/get-thefacts/renewable-energy-technologies/solarwall

[10]. Materials, G. B. (2009). GREEN BUILDING GUIDELINES FOR HOME REMODELING. Retrieved March 23, 2014, from www.builditgreen.org/_files/Admin/Collateral/BIG_Remodeling_07.pdf

[11]. Mishra, P. (2011). Green-Building-Thesis-Report-Administrative-Block-of-NIT-Raipur-New-Campus. Raipur.

[12]. Pachauri, D. R. (2007). GRIHA. Retrieved April 1, 2014, from Green Raiting for Integrated Habitat Assessment: http://www.grihaindia.org/

[13]. Ramesh S P, E. K. (2013). ENERGY EFFICIENCY IN GREEN BUILDINGS - INDIAN CONCEPT. International Journal of Emerging Technology and Advanced Engineering, 334-335.

[14]. Technology, G. R. (2014). Jörg Breuning \& Green Roof Service LLC. Retrieved March 4, 2014, from http://www.greenrooftechnology.com/

[15]. U.S. Environmental Protection. (n.d.). Retrieved March 14, 2014, from http://www.epa.gov/greenbuilding/pubs/about.htm 